Chapter 9

\title{
Challenges to Increased Soybean Production in Brazil
}

\author{
Hilton S. Pinto, Ana Maria H. de Avila and \\ Andrea O. Cardoso \\ Additional information is available at the end of the chapter \\ http://dx.doi.org/10.5772/52647
}

\section{Introduction}

Soybean (Glycine max (L.) Merril) is one the of the main sources of protein and vegetable oil of the world being grown commercially and used in animal and human feed for hundreds of years. Originally from Asia where the soybean was considered as sacred grain, next to rice, wheat, barley, millet to be essential to the stability of Chinese civilization.

According to EMBRAPA SOJA (2008) soybean is the main oleaginous grain cultivated in the world. In 2006/07 it contributed about $60 \%$ of the total 385 million tons of grain produced globally by major oil seeds (soybean, sunflower, canola, peanut, cotton and castor). According to Dall'agnoll and Hirakuri (2008) the high rates of increase in soybean world wide production (more than five million tons/year in the period 1970 to 2007) should continue due to the growth of the global population (70 million/year) and to the change in food consumption habits of the population.

On the other hand, the intense search for alternative sources of energy also stimulates consumption of soybean oil as a fuel. Thus, in the future soybean may also become a major energy crop. Although use rates are not increasing as much as for oil, demand for soybean as a livestock meal is also increasing. Since the early 1980sthe total consumption of soybean mealon a worldwide basishas grown about three times from the original 127.2 million tons. The expansion of income, especially in Asia, with the effect on the consumption of meats, especially poultryands wine, was the driver for the robust growth rate of soybean for the animal feed industry (Pinazza, 2007). Also according to Pinazza (2007), the long-term projections for soybeansin a global context shows that the total demand for soybeansis expected to grow around 3\% in the next ten years. The crushing world will grow from the current level of 174.8 million tons to253.9 million tons. 
Projections to 2015 indicate that from a world production of 71.5 million tons of soybeans, 66.4 million tons comes from the exporting countries Brazil, Argentina and the USA with 4.9 million from other countries. According to the Baseline Projections of the USDA, world GDP will continue growing at an annual average rate of $3.2 \%$. At the same time the world population is expected to grow in the same period at an annual rate of $1.1 \%$, to 6.87 billion people in 2015.

Soybean has enormous economical significance due to its high food value and its role in the vegetable oil industry as well in bio-diesel production. Leguminous plants are sources of various industrial enzymes, protein, fiber and unsaturated fat, and rich in vitamins and minerals, a nutritious meal with high food value. It has been explored worldwide for its inclusion in a variety of foods and is also an important constituent for animal feed. It is the source of various enzymes, particularly important in seed imbibitions and germination. Many of these enzymes have industrial significance and due to their plant origin are more acceptable, particularly by the food industry (Dwevedi and Kayastha, 2011).

According to FAPRI (2009), estimates for soybean grain indicate a Brazilian production of 86.5 million tons in 2020/2021. Soybean is expected to expand through a combination of initiating production in new areas where land is available and the substitution of soybean for crop land that is already in pasture land or other crops. The annual growth rate for soybean production land is expected to be $2.3 \%$ from now until 2020/2021 (Figure 1). This rate is close to the global rate for the next ten years, estimated by FAPRI (2009) at $2.30 \%$ per year. Domestic consumption of soybeans is expected to reach 45.6 million tons by 2020/2021, which represent $52.7 \%$ of Brazil's production. Consumption is projected to grow at an annual rate of $1.9 \%$.

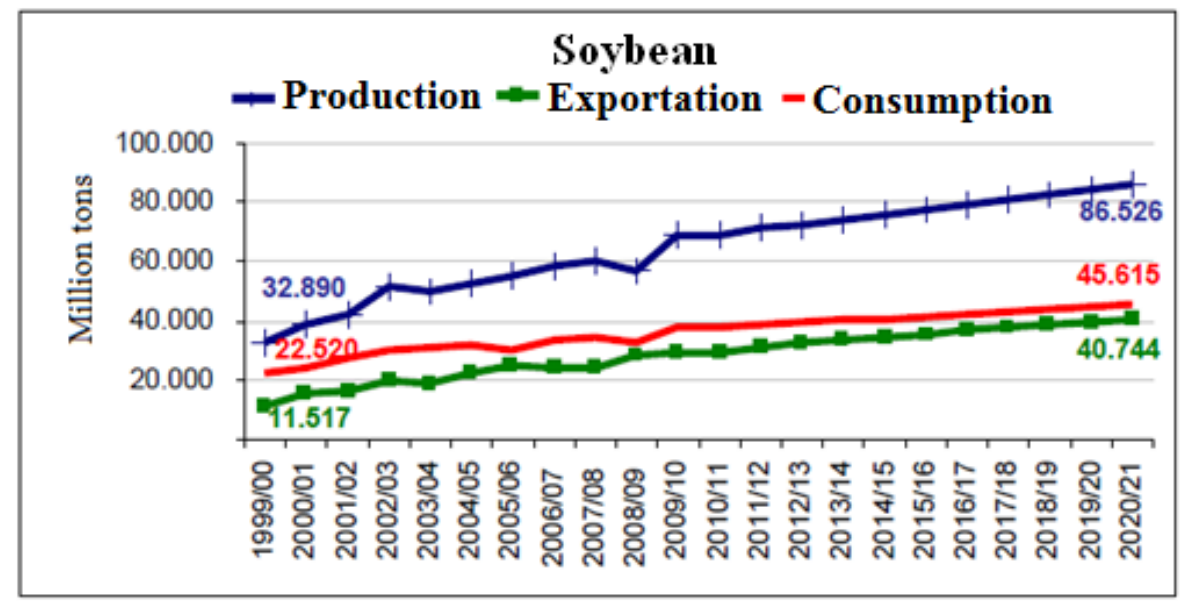

Figure 1. Production, exportation and consumption of soybean from Brazil (Source: Brasil Projeções do Agronegócio 2010/2021 - Ministério da Agricultura Pecuária e Abastecimento). 
Considering plant breeding technology the productive potential of a cultivar is obtained only if the culture is under optimal environmental conditions. However, in natural conditions for farming, a number of biotic and non biotic factors acting individually or interactively may prevent optimum conditions from occurring. Therefore, soybean can be exposed to many different stresses. To avoid reductions in crop yields it is essential to use management practices ranging from the choice of the variety best suited to your region, the proper management of soil and crops, rationalizing the use of lime, fertilizer and pesticides, to knowledge and use of market information that will allow you to maximize profits in the marketing of the crop.

Brazilian agriculture has shown a very high performance from 1995 to 2011 and is considered the largest worldwide exporter of soybeans. It accounts for 39\% of the total grain sold in the world. Brazil has potential to increase soybean production by conversion of up to 50 million hectares of degraded pasture land. Thus, biofuel production can be expanded without affecting either food production or the rainforest areas. Soybean is an ideal crop to restore fertility to degraded pastures in an integrated agriculture and livestock system due to the capacity to fix nitrogen from the air using bacteria in the root nodules.

Brazilian territory is located between the latitudes of $5^{\circ} \mathrm{N}$ and $33^{\circ} \mathrm{S}$ and consequently $93 \%$ of the country is located in the southern hemisphere. This region has a large variety of climates favorable to agricultural development that can be affected by global warming. A study done by Pinto et all, 2005 and 2008, based on the IPCC $(2001,2007)$ estimated that climate change would reduce the Brazilian soybean production area by $23 \%$ until 2020 unless measures were taken to develop adaptable varieties that are tolerant to drought and heat stress. The objective of this study is to predict the effects of climate change on the soybean industry of Brazil. The study follows the methodology used by the Ministries of Agriculture and Agrarian Development to outline production risks in different climatic zones of Brazil. Climatic risk zoning in the country is a public policy for farmers and establishes climatic risk levels for the different regions indicating optimal crops and planting dates for given locations.

Climatic risk zoning was determined for the period from 2030 through 2040. Based on climatic scenarios for given regions it was determined that in order to reduce crop risk, two main research areas needed to be addressed: adaptation of varieties through plant breeding research and improvement of the management system through new technologies in the field. The strategy is to develop plants adapted to high temperatures and water deficit. Cost estimates for the research project were based on an average period of 8-12 years for breeding and release of improved cultivars. The average total investment for the development of each cultivar was designed around US\$ 5 million or an average cost of 1 million Reais a year (1 $\mathrm{US} \$=2$ Reais)

Assad et al. (2007a) stated that for soybean production at higher elevations, the size of low climatic risk areas will decrease as the mean temperatures and rainfall increase for the main planting period. In Brazil, the total area with soybean cultivations in 2010/2011 was 24,2 million hectares with a total potential for future production of 86 million tons in 2020, without considering any climate change (CONAB, 2011). The biggest soybean production area in Brazil is the municipality of Sorriso, in Mato Grasso State, located in 
the Midwest region. A description of current areas suitable and unsuitable for soybean production is given in Figure 2.

In Brazil, soybean is the crop that will probably suffer most from global warming. According to studies by Pinto et al. (2008), this will create a different geographic distribution for the crop (Fig. 3), if current varieties and cultural practices are not changed. Financial losses from a reduction in production area could reach $\mathrm{R} \$ 7$ billion/year by 2070.

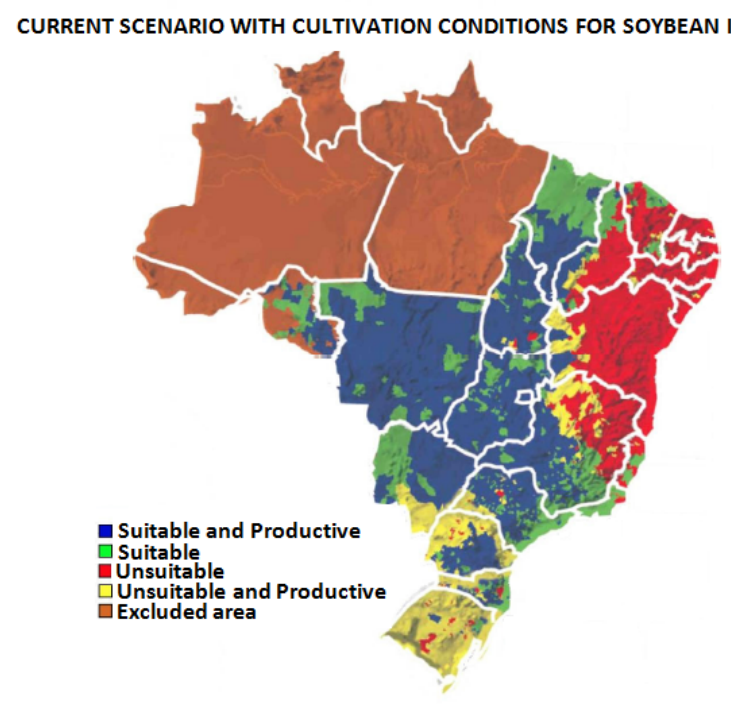

Figure 2. Geographical Distribution of soybean in Brazil (Source Pinto et al., 2008) showing the actual areas where the grain is already cultivated with low risk due to soil and climate conditions (blue), suitable but with no crop cultivation (green), unsuitable due to drought (red), not indicated by the risk zoning, but with soybean cultivation with low productivity (yellow) and not allowed due to permanent protection regions (brown).

By 2070 the low risk area for cultivation in Brazil is set to be $60 \%$ lower than that of today due to the decreased rainfall and the likelihood of more intense short summer droughts. The South of Brazil and the North-eastern Cerrado region will be affected more severely. The crop that currently has the highest production value in Brazilian agriculture - US\$17 billion (according to 2010 data) and is also the country's main agricultural export product, may suffer a $\mathrm{R} \$ 3.9$ billion to $\mathrm{R} \$ 4.3$ billion annual loss by 2020 (in scenarios IPCC A2 and B2, respectively) caused by reduction in the low risk area of $21.62 \%$ and $23.59 \%$ for A2 and B2 scenarios, respectively. In 2050 the loss may increase to somewhere between $\mathrm{R} \$ 5.47$ billion (B2) and R\$ 6.3 billion (A2), reflecting a reduction in low risk area of $29.6 \%$ to $34.1 \%$ compared with the 2010 production area. For 2070 in the more optimistic outlook the loss will be $\mathrm{R} \$ 6.4$ billion (- $34.86 \%$ of suitable land) and in the worst case scenario it will stand at $\mathrm{R} \$ 7.6$ billion $(-41.39 \%)$. 


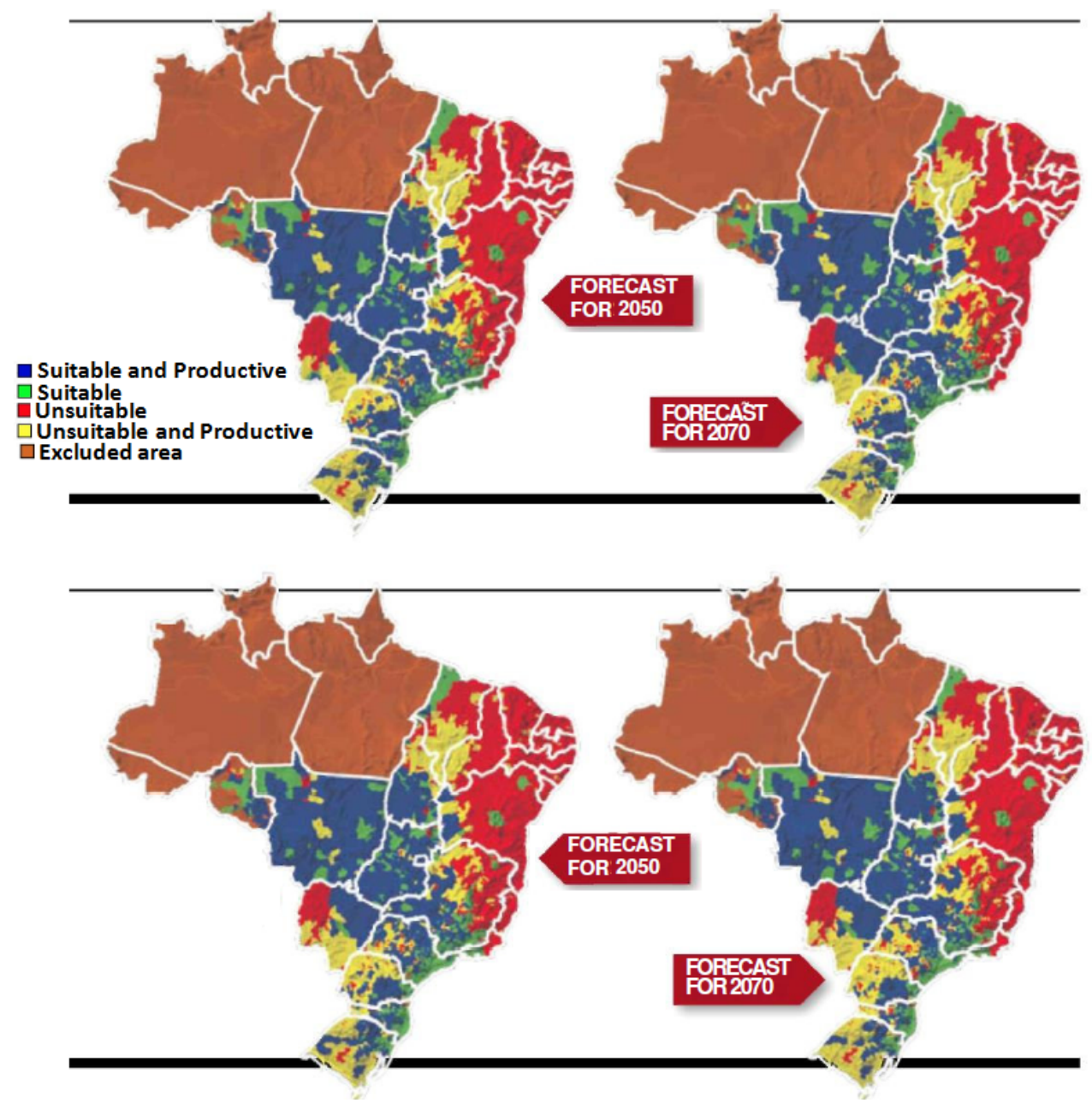

Figure 3. The geographical distribution of soybean in Brazil in 2050 and 2070 for the optimistic and pessimistic scenarios - B2 and A2 (Adapted from Pinto et al., 2008).

Despite the high vulnerability to climatic change detected in this study, agriculture has a great capacity of adaptation to new climatic conditions, depending on the technology available to deal with the problems. Assad et al. (2007b) highlighted the factors required for the adaptation of the main Brazilian crops: heat tolerance for the whole country, drought tolerance for the Southern and Northern regions and soil management to increase water conservation capacity. The biodiversity of the Cerrados and Amazon regions may contain genes that facilitate the adaptation of present crops to environmental stress and tolerate drought and heat. The substitution of crops or the use of more resistant varieties or species may be another method of adapting agriculture to climatic changes. Papers issued by Pinto et al. 
(2005, 2007, 2008), Zullo et al. (2006) and Assad et al. (2004) indicate that the higher elevation regions with colder and milder climate may become low climate risk areas for most part of crop production as temperatures increase with global warming.

According to Pinto and Assad (2008) the worst prediction for soybean in 2020, considering the climate scenario A2 made by the IPCC (2001) showed a $24 \%$ reduction in the low risk area for soybean cultivation in Brazil. A more recent study (Pinto and Assad, 2012) using a combination of 23 Global Climate Models (GCMs) indicated by AR4 WGI Report IPCC (2007) and three Regional Climate Models (RCMs) - PRECIS (Jones et al. 2004), ETA (Pisnichenko and Tarasova 2009) and BRAMS (Freitas et al. 2009) showed a decrease in the low risk area of the country also of $24 \%$ in the pessimistic scenario and of $13 \%$ in the optimistic one. The Brazilian government estimates a production of 86 million tons of soybean in 2020 without taking into account the reduction of low risk areas due to climate change. In this case, close to 20 million tons will be lost if the temperature continues to increase, or, in other words, at actual prices of US \$500/ton, Brazil will lose close to US\$ 10 billion/year.

However, at the same time, scientists are developing new soybean genotypes and cultivars which are more tolerant to high temperatures and droughts. The studies are at an advanced stage, but it should be underlined that, even if they result in more resistant plants, there is a limit to how far genetic improvement can go. The alterations are capable of handling the problem with up to a $2^{\circ} \mathrm{C}$ temperature rise. Above that mark, the plants begin to have difficulties in photosynthesizing, demanding the adoption of other measures. One alternative to this limitation could be the so-called second generation crops of Genetically Modified Organism (GMO).Instead of just being herbicide-tolerant or pest-resistant, these would be more suited to severe environmental conditions.

This proposal aims to find out plants that are naturally more tolerant for high temperatures and water shortages and use their genes to produce more resistant farm crops. Embrapa Cerrados is analyzing typical species of the biome which are more adapted to the characteristic variations in temperature and rainfall in the region.

The researchers have already identified five plants (broadleaf pauterra, small-leaf pau-terra, pacari, faveiro and sucupirapreta) which occur in over $80 \%$ of the biome, suggesting a high adaptive capacity. The next step is to isolate the genes which give them these characteristics. Similar studies are also being planned for the Caatinga region. The value of the biodiversity of the two biomes is yet another argument for the prevention of its deforestation.

Plant breeding research developed by Embrapa Soja at Londrina, Parana has already showed a prospective tolerant cultivar (Figure 4). Using the same water content in the soil $(2.5 \%)$ the modified cultivar shows a normal development when compared to a normal commercial soybean.

The general purpose of this study is to show the current potential of national agriculture to mitigate some problems related to global warming and to adapt the soybean research program accordingly. The purpose is to aid researchers in avoiding the potential problems that could occur as global warming continues to increase at its current pace. 


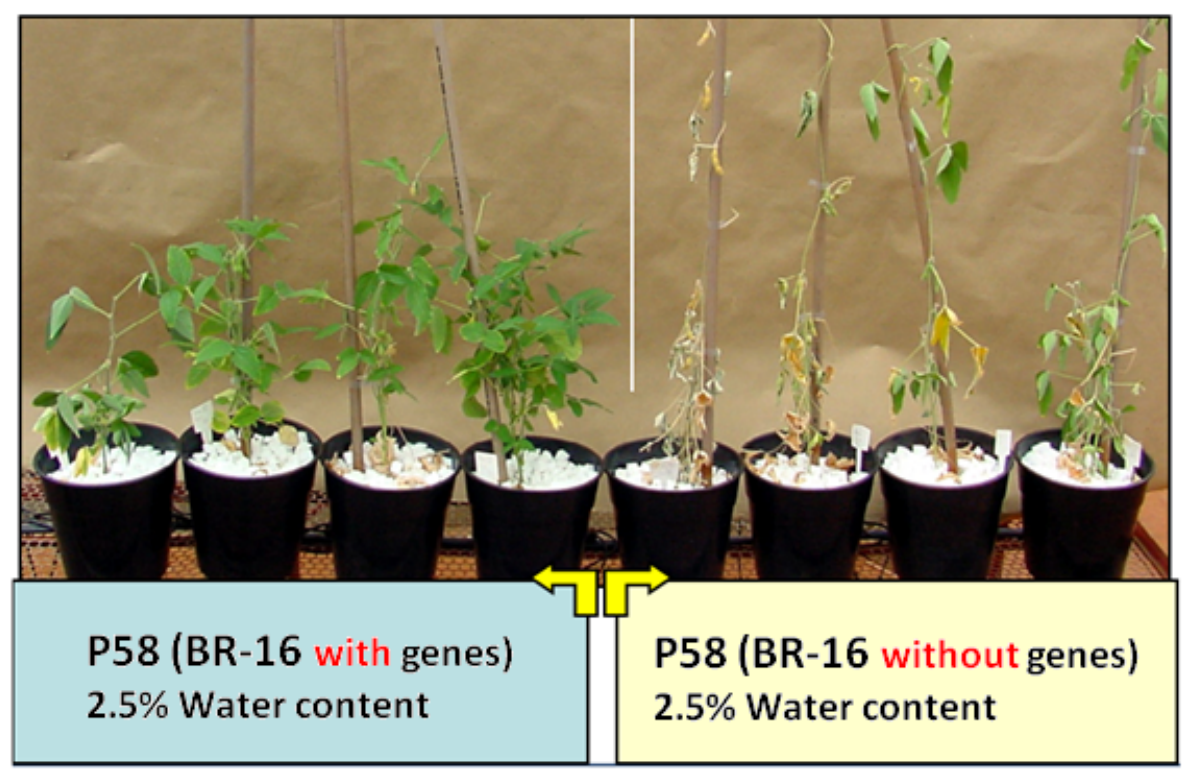

Figure 4. Gene expression drought-tolerance in soybeans (Source: Nepomuceno, A. L.-Embrapa Soja).

\section{List of acronyms}

BRAMS: Brazilian Developments on the Regional Atmospheric Modelling System)

CONAB: National Supply Company

EMBRAPA: Brazilian Agricultural Research Corporation

ETA: Greek Letter - Weather Forecast Model

FAPRI: Food and Agricultural Policy Research Institute

GCMs: Global Climate Models

GDP: Gross Domestic Product

GMO: Genetically Modified Organisms

IPCC: Intergovernmental Panel on Climate Change

PRECIS: Providing Regional Climates for Impacts Studies

RDMs: Regional Climate Models

WGI: Working Group I 


\section{Author details}

Hilton S. Pinto ${ }^{1}$, Ana Maria H. de Avila ${ }^{1}$ and Andrea O. Cardoso ${ }^{2}$

1 CEPAGRI, UNICAMP, Campinas - SP, Brazil

2 UFABC, Universidade Federal do ABC, Santo Andre, SP, Brazil

\section{References}

[1] Assad, E. D., Pinto, H. S., Zullo, J., Jr , , Ávila, e., \& de , A. M. H. (2004). Impacto das MudançasClimáticas no ZoneamentoAgroclimático do Café no Brasil. Pesq.Agrop.Bras.PAB.39(11)., 1057-1064.

[2] Assad, E. D., Pinto, H. S., Zullo, J., \& Jr 2007a, . (2007a). Impacts of Global Warming in the Brazilian Agroclimatic Risk Zoning. In: Silva Dias, P. L. S.; Ribeiro, W. C.; e Nunes, L. H. A Contribution to Understanding the Regional Impacts of Global Change in South America.IEA/USP. São Paulo, SP. http://www.iea.usp.br/iea/artigos/ globalchangeinsouthamerica.pd, 175-182.

[3] Assad, E. D., Pinto, H. S., Zullo, J. R. e., \& Marin, F. R. (2007). b MudançasClimáticas e Agricultura: umaAbordagemAgroclimatológica. Ciência e Ambiente 34. , 169-182.

[4] CONAB,(2011). Sojaemnúmeros (safra 2010/2011).http://www.cnpso.embrapa.br/ index.php?cod_pai=2\&op_page=294 Accessed in 13 Jul 2012.

[5] Dall'agnol, A., \& Hirakuri, M. H. (2009). Realidade e Perspectivas do BrasilnaProdução de Alimentos e Agroenergia, com ÊnfasenaSoja.Acessed in 12 march. 2012: http:// www.redeagroenergia.cnpm.embrapa.br.

[6] Alka, Dwevedi., Arvind, M., \& Kayastha, (2011. (2011). Soybean: a Multifaceted Legume with Enormous Economic Capabilities, Soybean- Biochemistry, Chemistry and Physiology, Prof. Tzi-Bun Ng (Ed.), 978-9-53307-219-7InTech, Available from: http:// www.intechopen.com/books/soybean-biochemistry-chemistry-and-physiology/ soybean-a-multifaceted-legume-with-enormous-economic-capabilities

[7] EMBRAPA SOJA.(2008). EmpresaBrasileira de PesquisaAgropecuária.Disponívelem: http://www.cnpso.embrapa.br.Accessed in: 16 march. 2012.

[8] FAPRI.(2009). U.S and world Agricultural Outlook. FAPRI Staff Report FSR 1 1534-4533Food and Agricultural Policy Research Institute- Iowa State University University of Missouri-Columbia Ames, Iowa. U.S.A., 09.

[9] Freitas, S. R., Longo, K. M., Silva, Dias. M. A. F., Chatfield, R., Silva, Dias. P., Artaxo, P., Andrea, M. O., Grell, G., Rodrigues, L. F., Fazenda, A., \& Panetta, J. (2009). The Coupled Aerosol and Tracer Transport Model to the Brazilian Development on the 
Regional Atmospheric Modeling System (CATT-BRAMS). Part 1: Model Description and Evaluation. Atmospheric Chemistry and Physics 9., 2843-2861.

[10] Hirakuri, M. H. Estimativa de custo de produção e lucratividade da soja, safra (2008/09). para o Paraná e Santa Catarina.Londrina: EmbrapaSoja, 2008. 15 p. (EmbrapaSoja.Circular Técnica, 65).

[11] IPCC.(2001). Third Assessment Report. Climate Change 2001.The Physical Science Basis.Summary for Policymakers.

[12] IPCC.(2007). Fourth Assessment Report. Climate Change.The Physical Science Basis.Summary for Policymakers.

[13] Jones, R. G., Noguer, M., Hassell, D. C., Hudson, D., Wilson, S. S., Jenkins, G. J., \& Mitchell, J. F. B. (2004). Generating Hight Resolution Climate Change Scenarios Using PRECIS.Met Office Hadley Centre. Exeter, UK, 40 pp.

[14] MAPA- Ministério da Agricultura, Pecuária e Abastecimento.(2007). Secretaria de Política Agrícola. Instituto Interamericano de Cooperação para a Agricultura- IICA. Série Agronegócios. Cadeia Produtiva da Soja. , 2

[15] MAPA- Ministério da Agricultura, Pecuária e Abastecimento- Assessoria de GestãoEstratégica.(2011). Brasilprojeções do Agronegócio 2010/2011 a 2020/2021.

[16] Pinazza, L. A. ., \& Coord, . Cadeia produtiva da soja. Brasília, DF: Ministério da Agricultura, Pecuária e Abastecimento: IICA, (2007). p (MAPA.Agronegócios, , 1

[17] Pinto, H. S., Assad, E. D., \& 201, . (2012). Impacts of Climate Change on Brazilian Agriculture. In: Brazil: Assessment of the Vulnerability and Impacts of Climate Change on Brazilian Agriculture. Development report for World Bank Project Coord. Erick C.M. Fernandes. May, 25- 2012., 118037.

[18] Pinto, H. S. e., \& Assad, E. D. (2008). Global Warming and The New Geography of Agricultural Production in Brazil. The British Embassy. Brasília, DF. 42 pp. Disponívelem: http://www.cpa.unicamp.br/aquecimento_agricola_en.html.

[19] Pinto, H. S., Zullo, J. R. J., Assad, E. D. e., Avila, A. M. H., \& de , . (2005). th International Congress of Biometeorology. Annalen der Meteorologie, , 1, 223-226.

[20] Pinto, H. S., Zullo, J. J. R., Assad, E. D. e., \& Evangelista, B. A. (2007). O Aquecimento Global e a CafeiculturaBrasileira. Boletim da SociedadeBrasileira de Meteorologia., 65-72.

[21] Pisnichenko, I. A., Tarasova, T. A., \& 200, . (2009). Climate Version of the ETA Regional Forecast Model.TheorApplClimatol. Spring-Verlag. 18 pp. Published online 05 May, 2009.

[22] Zullo, J. R. J., Pinto, H. S. e., \& Assad, E. D. (2006). Impact Assessment Study of Climate Change on Agricultural Zoning.MeteorolAppl 13(S1)., 69-80. 
